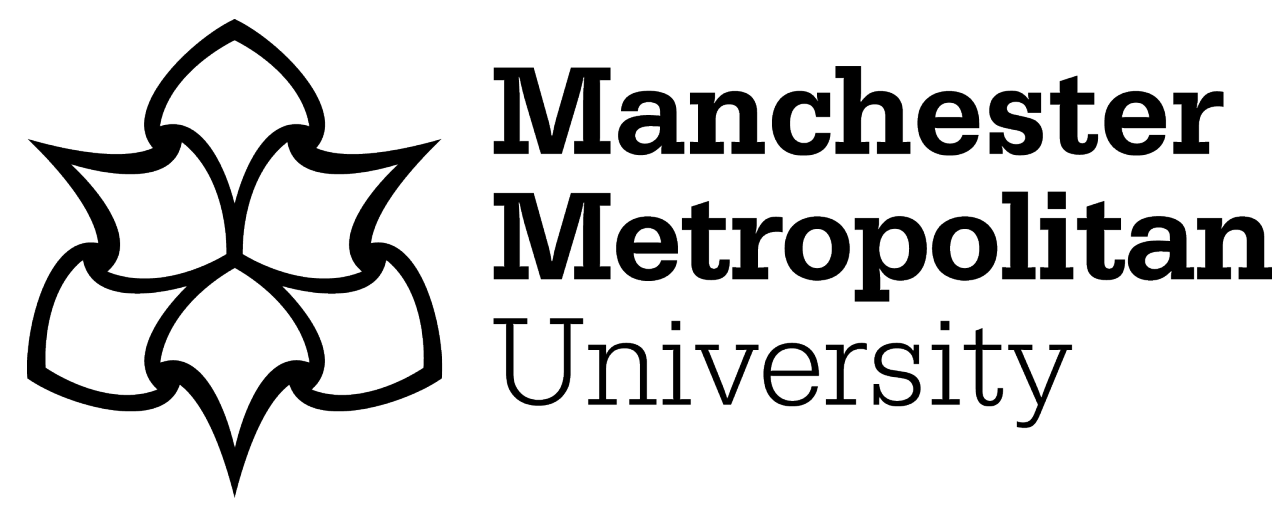

Britten, TK ORCID logoORCID: https://orcid.org/0000-0002-3580-1145, Akien, GR, Kemmitt, PD, Halcovitch, NR and Coote, SC (2019) An efficient preparation of 1,2-dihydropyridazines through a Diels-Alder/palladiumcatalysed elimination sequence. Tetrahedron Letters, 60 (22). pp. 14981500. ISSN 0040-4039

Downloaded from: https://e-space.mmu.ac.uk/625607/

Version: Accepted Version

Publisher: Elsevier

DOI: https://doi.org/10.1016/j.tetlet.2019.04.054

Please cite the published version 


\section{An Efficient Preparation of 1,2-Dihydropyridazines Through a Diels-Alder/Palladium-Catalyzed Elimination Sequence}

Thomas K. Britten, ${ }^{+}$Geoffrey R. Akien, ${ }^{+}$Paul D. Kemmitt, ${ }^{\ddagger}$ Nathan R. Halcovitch ${ }^{+}$and Susannah C. Coote ${ }^{+*}$

${ }^{+}$Department of Chemistry, Lancaster University, Lancaster, LA1 4YB, UK

‡ Oncology, IMED Biotech Unit, AstraZeneca, Cambridge, UK

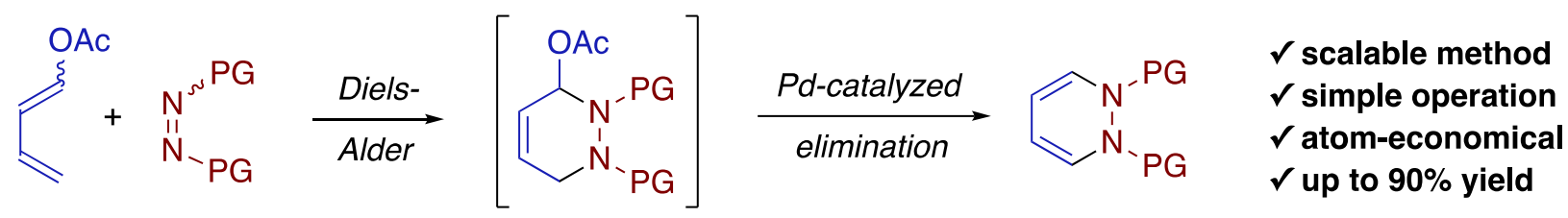

ABSTRACT: A convenient and scalable synthesis of 1,2-dihydropyridazines is presented, based on the Diels-Alder cycloaddition of 1-acetoxy-1,3-butadiene with a variety of azo compounds, followed by a palladium-catalyzed elimination. The products are produced on gram-scale and the new method is particularly efficient and atom-economical when compared with previously published preparations of 1,2-dihydropyridazines.

For ongoing projects, we required ready access to multigram quantities of 1,2-dihydropyridazines 2, which have only rarely been described in the literature. ${ }^{1-6}$ We felt that 1,2 -dihydropyridazines represent potentially interesting molecular building blocks, envisioning selective double-bond functionalisations, diene-type reactivity and N-N bond cleavage providing access to a wide variety of different molecular scaffolds. Indeed, preliminary studies have shown that simple 1,2dihydropyridazines undergo electrocyclic reactions, ${ }^{1 a, 2-4,7}$ (producing bicyclic diazetidines, 2aminopyrroles and conjugated imines) as well as Diels-Alder reaction with 4-phenyl-1,2,4triazole-3,5-dione (PTAD), ${ }^{5,8}$ whilst more substituted 1,2-dihydropyridazines have been used as precursors to substituted pyridazine derivatives. ${ }^{9}$ In addition, unusual photochemical reactions of selected 1,2-dihydropyridazines have also been reported. ${ }^{10}$

To enable a more comprehensive study of the synthetic potential of 1,2-dihydropyridazines $\mathbf{2}$, we required an efficient synthesis suitable for multigram scale. Initially, we assessed previously described routes to 1,2-dihydropyridazines 2, starting with an approach first reported by Altman and co-workers, $^{1}$ (and later employed by other authors), ${ }^{2-4}$ which involves the Diels-Alder cycloaddition of 1,3-butadiene with dimethyl azodicarboxylate to give tetrahydropyridazine 1, followed by allylic bromination then dehydrobromination to generate $\mathbf{2}$ (Scheme 1). Whilst the initial Diels-Alder cycloaddition proceeded as expected with a range of azodicarboxylate reagents, the requirement for carbon tetrachloride (a toxic and ozone-depleting chemical) in the allylic bromination step is a major disadvantage. Unfortunately, our attempts to identify more sustainable reaction conditions for the allylic bromination were unsuccessful, thus we turned our attention to a related synthetic approach, ${ }^{5,6}$ in which tetrahydropyridazine $\mathbf{1}$ is converted into dihydropyridazine $\mathbf{2}$ via a bromination/double dehydrobromination sequence (Scheme 1). However, the process proved capricious, and only poor yields of impure dihydropyridazines could 
be obtained after the bromination/elimination sequence. Hence, as the existing synthetic routes to $\mathbf{2}$ were unsuitable for larger-scale work, we sought to develop a new scalable synthetic approach to 1,2-dihydropyridazines $\mathbf{2}$ by incorporating a suitable leaving group (LG) into the diene 3, thereby allowing elimination directly from the resulting cycloadduct $\mathbf{4}$ and negating the need for bromination procedures.

\section{Scheme 1. Overview of Synthetic Approaches to 1,2-Dihydropyridazines}

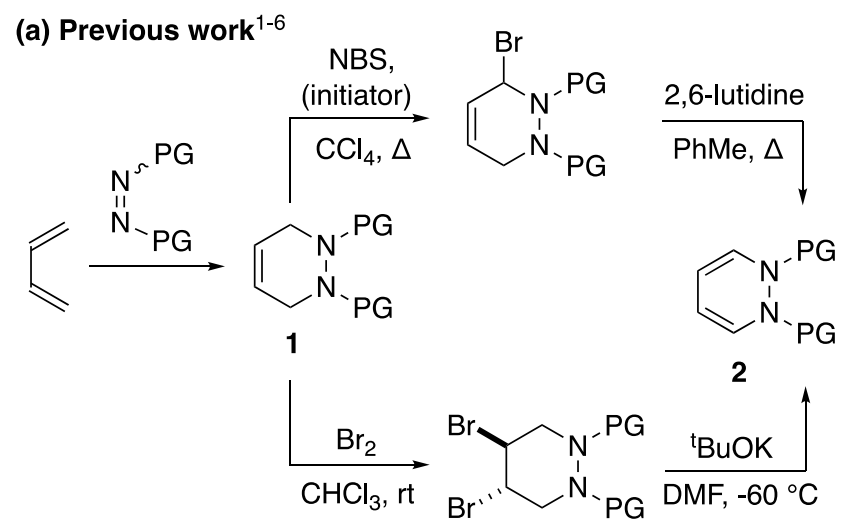

(b) This work

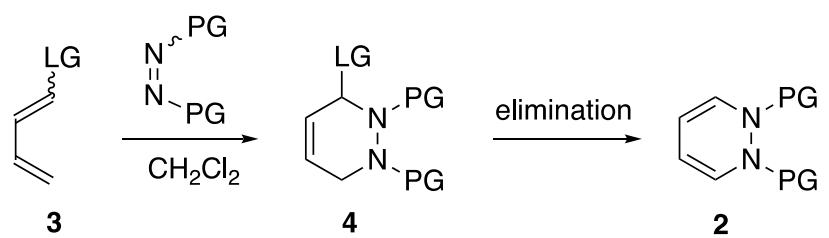

Scheme 1 Footnote: $P G=$ protecting group, $L G=$ leaving group, NBS = N-bromosuccinimide, DMF = dimethylformamide.

At the outset, the Diels-Alder cycloadditions of diisopropyl azodicarboxylate (DIAD) with a range of substituted dienes 3 ( $\mathrm{LG}=\mathrm{OAc}, \mathrm{OBz}$, OPiv or $\mathrm{OCO}_{2} \mathrm{Et}$ ) were studied, generating tetrahydropyridazine intermediates 4 . Of the dienes tested, 1-acetoxy-1,3-butadiene (3a; $L G=$ OAc) gave the most promising results in terms of the stability and the isolated yield of the resulting cycloadduct $\mathbf{5 c}$, which was sufficiently stable to purification by flash column chromatography (although some degradation during purification was observed, pure samples of $5 \mathbf{c}$ were readily obtained). Next, attention turned to the elimination of intermediate $\mathbf{5 c}$ to give 1,2-dihydropyridazine $\mathbf{2 c}$. Initially, the elimination was attempted under a range of mild acidic or basic conditions, but in these cases the starting material was recovered unchanged. When more forcing acidic or basic conditions were employed, no 1,2-dihydropyridazine product 2c was obtained, but significant decomposition of the starting material took place. Therefore, we wondered whether the desired transformation could be carried out using palladium catalysis. Whilst the palladium-catalyzed elimination of allylic acetates is well known, ${ }^{11}$ to our knowledge 
there is no precedent for palladium-catalyzed elimination in heterocyclic systems such as $\mathbf{5}$. Pleasingly, the application of a variety of palladium catalysts resulted in conversion of $\mathbf{5 c}$ into $\mathbf{2 c}$, although in some cases, rearrangement of the starting material (to produce allylic acetate $6 \mathrm{c}$ ) was observed in addition to the desired elimination process (Table 1). Interestingly, the palladiumcatalyzed elimination of allylic acetate $6 c$ to $2 c$ was extremely sluggish, therefore it was crucial to suppress the formation of $6 c$ to allow efficient conversion of $5 c$ to $2 c$.

\section{Table 1. Optimisation of the Palladium-Catalyzed Elimination of Allylic Acetate 5c}

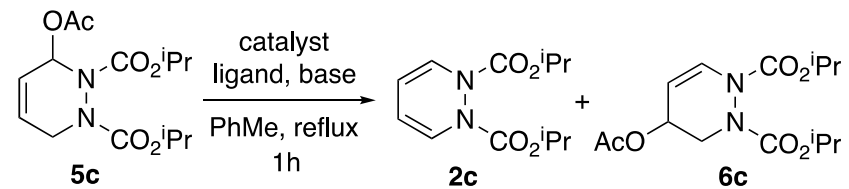

\begin{tabular}{|c|c|c|c|c|c|}
\hline entry & catalyst & ligand & base & $\begin{array}{l}\text { yield }^{\mathrm{a}} \\
\mathbf{2 c}(\%)\end{array}$ & $\begin{array}{l}\text { yield }^{\mathrm{a}} \\
\mathbf{6 c}(\%)\end{array}$ \\
\hline 1 & $\begin{array}{l}\mathrm{Pd}\left(\mathrm{PPh}_{3}\right)_{4} \\
(10 \mathrm{~mol} \%)\end{array}$ & - & - & 73 & 15 \\
\hline 2 & $\begin{array}{c}\mathrm{Pd}_{2}(\mathrm{dba})_{3} \\
(10 \mathrm{~mol} \%)\end{array}$ & $\begin{array}{c}\mathrm{PPh}_{3} \\
(40 \mathrm{~mol} \%)\end{array}$ & - & $48^{\mathrm{b}}$ & - \\
\hline 3 & $\begin{array}{l}\mathrm{Pd}(\mathrm{OAc})_{2} \\
(10 \mathrm{~mol} \%)\end{array}$ & $\begin{array}{c}\mathrm{PPh}_{3} \\
(40 \mathrm{~mol} \%)\end{array}$ & - & 77 & - \\
\hline 4 & $\begin{array}{l}\mathrm{Pd}(\mathrm{OAc})_{2} \\
(10 \mathrm{~mol} \%)\end{array}$ & $\begin{array}{c}\text { dppp } \\
(20 \mathrm{~mol} \%)\end{array}$ & - & $42^{c}$ & $39^{c}$ \\
\hline 5 & $\begin{array}{l}\mathrm{Pd}(\mathrm{OAc})_{2} \\
(10 \mathrm{~mol} \%)\end{array}$ & $\begin{array}{c}\text { Xantphos } \\
(20 \text { mol\%) }\end{array}$ & - & 76 & - \\
\hline 6 & $\begin{array}{l}\mathrm{Pd}(\mathrm{OAc})_{2} \\
(1 \mathrm{~mol} \%)\end{array}$ & $\begin{array}{l}\text { Xantphos } \\
(2 \mathrm{~mol} \%)\end{array}$ & - & 17 & 47 \\
\hline 7 & $\begin{array}{l}\mathrm{Pd}(\mathrm{OAc})_{2} \\
(1 \mathrm{~mol} \%)\end{array}$ & $\begin{array}{c}\mathrm{PPh}_{3} \\
(4 \mathrm{~mol} \%)\end{array}$ & $\mathrm{NEt}_{3}$ & 83 & - \\
\hline
\end{tabular}

Table 1 footnote: alsolated yield of product (column chromatography) ${ }^{b}$ Difficulties encountered

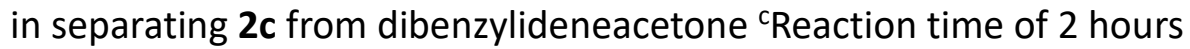

Several different palladium catalysts were tested, with $\mathrm{Pd}(\mathrm{OAc})_{2}$ proving optimal, although the choice of ligand had a strong effect on the selectivity for $\mathbf{2 c}$ over $\mathbf{6 c}$. Thus, whilst the use of dppp gave approximately equal amounts of $\mathbf{2 c}$ and $\mathbf{6 c}$, Xantphos and triphenylphosphine led selectively to $\mathbf{2 c}$ in good yields. However, using Xantphos, reducing the catalyst loading from $10 \mathrm{~mol} \%$ to 1 mol\% switched the selectivity to give $6 c$ as the major product (compare entries 5 and 6 ). In contrast, no such loss in selectivity was observed when $\mathrm{Pd}(\mathrm{OAc})_{2}$ /triphenylphosphine was employed at low catalyst loading, and the desired product $\mathbf{2 c}$ could be selectively obtained in excellent yield using only 1 mol\% $\mathrm{Pd}(\mathrm{OAc})_{2}$ (entry 7 ). In this case, the inclusion of two equivalents of triethylamine led to more reproducible results. After further optimisation of the elimination 
conditions (see the Supporting Information), $\mathrm{Pd}(\mathrm{OAc})_{2}$, triphenylphosphine, triethylamine and 1,4-dioxane emerged as the optimal catalyst, ligand, base and solvent respectively.

Having identified optimised conditions for the elimination, the two-step cycloadditionelimination sequence was next applied to a range of different azo compounds. Thus, in addition to DIAD, diene 3a also underwent successful cycloaddition with five other symmetrical azodicarboxylate reagents to generate the corresponding acetoxytetrahydropyridazines $\mathbf{5}$, each bearing different carbamate protecting groups (Scheme 2). Moreover, two non-symmetrical azodicarboxylate reagents were also investigated, yielding tetrahydropyridazine products $\mathbf{5} f$ and $5 \mathrm{~g}$, each bearing two orthogonal protecting groups. The acetoxytetrahydropyridazine intermediates 5 required only a rapid purification through a short plug of silica (to remove excess diene 3a) before being subjected to elimination to give the desired 1,2-dihydropyridazines 2 (Scheme 2).

Scheme 2. Preparation of 1,2-Dihydropyridazines through Diels-Alder Reaction/PalladiumCatalyzed Elimination ${ }^{\mathrm{a}, \mathrm{b}}$

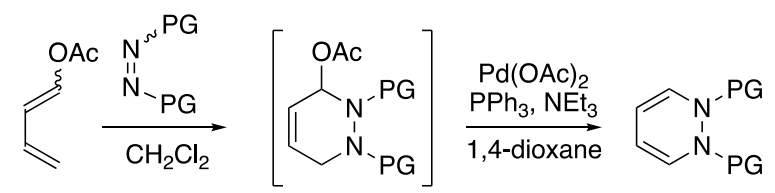

$3 a$

5

2

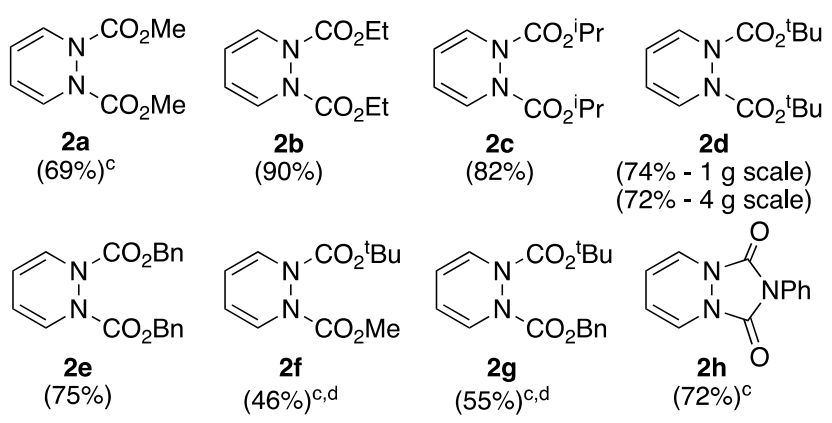

Footnote for Scheme 2: ${ }^{2}$ Reaction conditions: 3a (1.5 equiv.), azo compound (1.0 equiv.; 4.0-7.0 mmol), $\mathrm{CH}_{2} \mathrm{Cl}_{2}(2.5-5.0 \mathrm{M})$, rt or $40{ }^{\circ} \mathrm{C}, 1-40 \mathrm{~h}$, then Pd(OAc) 2 (1 mol\%), PPh 3 (4 mol\%), NEt 3 (2.0 equiv), 1,4-dioxane $(0.5 \mathrm{M})$, reflux, $1 \mathrm{~h}$; bsolated yields over two steps after column chromatography; 'As footnote a, but yield calculated over three steps also including synthesis of the azo compound from the corresponding hydrazine; ${ }^{d}$ As footnote a, but the elimination was carried out using $2 \mathrm{~mol} \% \mathrm{Pd}(\mathrm{OAc})_{2}$ and $8 \mathrm{~mol}_{\%} \mathrm{PPh}_{3}$.

The elimination procedure was applied to the eight different cycloadducts 5, allowing the preparation of the corresponding 1,2-dihydropyridazines $\mathbf{2}$ on gram-scale in generally high yields (Scheme 2). Product yields are calculated over two steps (the Diels-Alder cycloaddition and the subsequent elimination), when using commercially available azodicarboxylate reagents (i.e. for 
$\mathbf{2 b}, \mathbf{2 c}, \mathbf{2 d}$ and $\mathbf{2 e}$ ), whereas for 1,2-dihydropyridazines $\mathbf{2 a}, \mathbf{2 f}, \mathbf{2} \mathbf{g}$ and $\mathbf{2 h}$, the yields are calculated over three steps, including the preparation of the azodicarboxylate reagent from the corresponding hydrazine. In the case of $\mathbf{2 f}$ and $\mathbf{2} \mathbf{g}$, lower yields were obtained than those for the other 1,2-dihydropyridazines, due to the competing formation of rearrangement products $\mathbf{6 f}$ and $\mathbf{6 g}$ respectively. Doubling the catalyst loading resulted in improved yields of $\mathbf{2 f} / \mathbf{2 g}$ compared with those obtained under the standard conditions (46\% yield compared with $22 \%$ yield for $\mathbf{2 f}$; $55 \%$ yield compared with $43 \%$ yield for $\mathbf{2 g}$ ), but in these cases the rearrangement pathway could not be completely suppressed. It should also be noted that in general, the presence of water tends to promote the formation of rearrangement products $\mathbf{6}$, therefore the cycloadducts 5 were generally dried in a vacuum dessicator prior to the elimination step. Overall, the two-step reaction sequence is easy to perform and is scalable, as demonstrated by the four-fold scale-up of the synthesis of 1,2-dihydropyridazine $\mathbf{2} \mathbf{d}$, which produced four grams of $\mathbf{2} \mathbf{d}$ in comparable yield to that obtained on gram-scale.

The ${ }^{1} \mathrm{H}$ and ${ }^{13} \mathrm{C}$ NMR spectra of 1,2-dihydropyridazines $\mathbf{2 a - g}$ are complex, and deserve some comment. At room temperature, broad signals are generally observed, and at least two species are apparent that are in the immediate exchange regime on the NMR timescale. At $75^{\circ} \mathrm{C}$, (partial) coalescence of the peaks occurs, thus simplifying the spectra considerably (see the Supporting Information for variable-temperature NMR studies on 1,2-dihydropyridazine $\mathbf{2 b}$ ), whilst upon heating over $100{ }^{\circ} \mathrm{C}$, degradation occurs. These observations mirror those of Anderson and Lehn, who reported that diethyl 3,6-diphenyl-1,2-pyridazinedicarboxylate is non-planar in solution, based on ${ }^{1} \mathrm{H}$ NMR spectroscopic data that indicated a non-symmetrical structure. ${ }^{12}$ In this case, the authors suggested the presence of slowly equilibrating "twisted" conformations similar to those reported for 1,3-cyclohexadiene. ${ }^{13}$ In contrast, Fisher and co-workers studied the same dihydropyridazine by ${ }^{13} \mathrm{C}$ NMR spectroscopy, and concluded that a symmetrical species was present, as only one set of resonances was observed. ${ }^{14}$ Finally, Kaftory and co-workers concluded from their crystallographic study that the twist-boat conformation observed in the solid state is likely also predominant in solution. ${ }^{15}$ To our knowledge, no spectral data have been reported for other 1,2-dihydropyridazines, but our ${ }^{1} \mathrm{H}$ and ${ }^{13} \mathrm{C}$ NMR data (for 2a-g) are consistent with a dynamic ring-twisting process in line with that described by Anderson and Lehn, and NMR data for $\mathbf{2 a - 2} \mathbf{g}$ are provided at both ambient and elevated temperatures. Analysis of a single crystal of 2c confirmed a twisted conformation in the solid state (Figure 1), which is similar to that reported by Kaftory and co-workers, and apparent in the solid-state structure of $2 \mathrm{c}$ due to the large $\mathrm{C}-\mathrm{N}-\mathrm{N}$ C torsion angle of $44.74(11)^{\circ}$ as well as the $\mathrm{C}=\mathrm{C}-\mathrm{C}=\mathrm{C}$ torsion of $17.87(14)^{\circ}$.

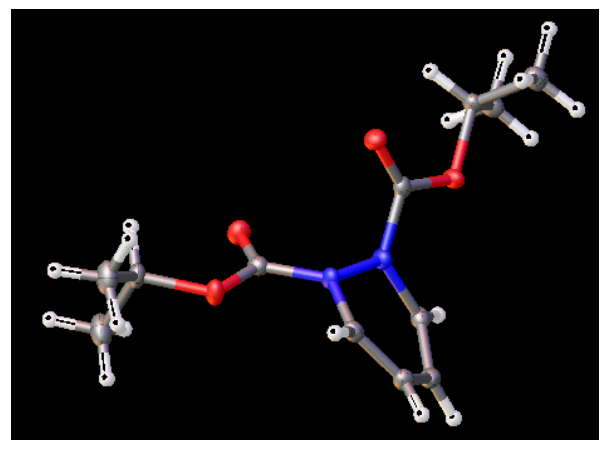


Figure 1. Solid-state molecular structure of $\mathbf{2 c}$ with thermal ellipsoids drawn at $50 \%$ probability.

In contrast, dihydropyridazine $\mathbf{2 h}$ does not exhibit this ring-twisting behaviour (a single set of resonances is observed by ${ }^{1} \mathrm{H}$ and ${ }^{13} \mathrm{C}$ NMR spectroscopy), presumably due to the lack of conformational freedom afforded by its fused bicyclic structure. It should be noted that several detailed spectroscopic analyses on tetrahydropyridazines have been reported, ${ }^{16}$ which display similar dynamic behavior to dihydropyridazines $\mathbf{2 a - g}$.

In summary, we have developed a new method for the preparation of 1,2-dihydropyridazines based on a novel Diels-Alder/palladium-catalyzed elimination sequence, which is particularly efficient and easy to perform when compared with the previously published synthetic routes. The two-step sequence is readily scalable, producing multigram quantities of 1,2-dihydropyridazines, and this convenient synthetic approach will enable detailed studies into the synthetic potential of these interesting heterocycles. Indeed, further work towards this goal is already underway, and will be reported in due course.

\section{EXPERIMENTAL SECTION}

\section{General Methods and Materials}

Reagents were purchased in the highest purity available from Acros Organics, Alfa Aesar and Sigma Aldrich. Anhydrous solvents used in reactions were purchased from Acros Organics equipped with AcroSeal ${ }^{\mathrm{TM}}$ and all other solvents used were of reagent grade. Triphenylphosphine was recrystallized from hexane prior to use. Brine refers to a saturated aqueous solution of sodium chloride, and water is distilled water. Reaction vessels were oven dried and cooled under an argon atmosphere prior to use and experiments were performed under argon gas. Palladium reactions were performed in Biotage $5-\mathrm{mL}$ or $20-\mathrm{mL}$ microwave vials and sealed with a cap. Reactions were monitored by thin-layer chromatography (TLC) and/or ${ }^{1} \mathrm{H}$ NMR spectroscopic analysis.

Analytical TLC was carried out using Merck pre-coated aluminum-backed TLC silica gel plates (silica gel $60 \mathrm{~F}_{254}$ ) and the plates were visualised by UV light $(254 \mathrm{~nm}$ ) and by staining with either potassium permanganate or aqueous acidic ammonium molybdate(IV). Normal phase flash column chromatography on silica gel was carried out using silica gel from VWR (40-63 microns).

${ }^{1} \mathrm{H}$ NMR spectroscopic data were obtained on either 300 or $400 \mathrm{MHz}$ instruments and ${ }^{13} \mathrm{C}\left\{{ }^{1} \mathrm{H}\right\}$ NMR data were obtained at $100 \mathrm{MHz}$ (Bruker Ultrashield 400 Plus) at $298 \mathrm{~K}$ unless otherwise specified. The chemical shifts are reported in parts per million $(\delta)$ relative to residual $\mathrm{CHCl}_{3}\left(\delta_{H}=\right.$ $7.26 \mathrm{ppm})$ and $\mathrm{CDCl}_{3}\left(\delta_{\mathrm{C}}=77.16 \mathrm{ppm}\right.$, central line), residual $d_{5}$-DMSO $\left(\delta_{\mathrm{H}}=2.50 \mathrm{ppm}\right)$ and $d_{6^{-}}$ DMSO $\left(\delta_{C}=39.52 \mathrm{ppm}\right)$. The assignment of the signals in the ${ }^{1} \mathrm{H}$ and ${ }^{13} \mathrm{C}$ NMR spectra was achieved through 2D-NMR techniques: COSY, HSQC and HMBC. Coupling constants $(J)$ are quoted in Hertz. Infrared spectra were recorded on an Agilent Technologies Cary 630 FTIR spectrometer. Melting points were performed on a Sanyo Gallenkamp capillary melting point apparatus and are uncorrected. High resolution mass spectrometry data were recorded using electron spray 
ionization (ESI) or atmospheric pressure chemical ionization (APCI) on a Shimadzu LCMS-IT-TOF mass spectrometer.

General procedure A: Synthesis of hydrazine-1,2-dicarboxylates from carbazates

Pyridine (3.0-6.0 eq) was added dropwise to a stirred solution of carbazate (1.0 eq.) and the desired chloroformate (1.1-1.2 eq.) in 2-MeTHF (0.5 or $1 \mathrm{M}$ ) at $0{ }^{\circ} \mathrm{C}$ under argon. The resulting suspension was stirred at $0{ }^{\circ} \mathrm{C}$ for 15 minutes and then at room temperature for 1.5 hours. A $10 \%$ $(\mathrm{v} / \mathrm{v})$ aqueous solution of $\mathrm{HCl}(10 \mathrm{~mL})$ was added and the mixture was extracted with $\mathrm{CH}_{2} \mathrm{Cl}_{2}(5 \mathrm{x}$ $20 \mathrm{~mL})$. The combined organic layers were washed with brine $(10 \mathrm{~mL})$, dried $\left(\mathrm{MgSO}_{4}\right)$ and evaporated under reduced pressure to give the crude product. If purification was required, the crude product was purified by flash column chromatography using an appropriate solvent system, as described for each individual procedure.

General procedure B: Synthesis of 1,2-dihydropyridazines starting from commercially available azo compounds

1-Acetoxy-1,3-butadiene (1.5 eq.) was added in one portion to a solution of the azo compound (1.0 eq.) in $\mathrm{CH}_{2} \mathrm{Cl}_{2}$ (2.5 or $5 \mathrm{M}$ ) and stirred at either room temperature or $40{ }^{\circ} \mathrm{C}$ for a specific length of time depending on the azo compound. The reaction mixture was evaporated under reduced pressure and the crude product was passed through a short silica gel column using an appropriate solvent system, as described for each individual procedure, to give the cycloadducts that contained minor impurities. The cycloadducts were dried in a desiccator, dissolved in 1,4dioxane $(0.5 \mathrm{M})$ and added to an oven-dried microwave vial (under argon) that contained $\mathrm{Pd}(\mathrm{OAc})_{2}$ (1.0 mol\%), $\mathrm{PPh}_{3}(4.0 \mathrm{~mol} \%)$ and triethylamine (2.0 eq.) The vial was sealed, then heated at reflux for 1 hour. The reaction mixture was cooled to room temperature and evaporated under reduced pressure to give the crude product. The crude product was purified by flash column chromatography using an appropriate solvent system, as described for each individual procedure.

General procedure C: Synthesis of 1,2-dihydropyridazines starting from hydrazine-1,2dicarboxylates

1-Acetoxy-1,3-butadiene (1.5 eq.) was added in one portion to a suspension of hydrazine-1,2dicarboxylate (1.0 eq.) and iodobenzene diacetate (1.0 eq.) in $\mathrm{CH}_{2} \mathrm{Cl}_{2}(0.6,1.0$ or $2.5 \mathrm{M}$ ) and stirred at either room temperature or $40{ }^{\circ} \mathrm{C}$ for a specific length of time depending on the azo compound. The reaction mixture was evaporated under reduced pressure and the crude product was passed through a short silica gel column using an appropriate using an appropriate solvent system, as described for each individual procedure, to give the cycloadducts that contained minor impurities. The cycloadduct was dried in a desiccator, dissolved in 1,4-dioxane (0.5 M) and added to an oven-dried microwave vial (under argon) that contained $\mathrm{Pd}(\mathrm{OAc})_{2}\left(1.0 \mathrm{~mol}^{2}\right), \mathrm{PPh}_{3}(4.0$ mol\%) and triethylamine (2.0 eq.) The vial was sealed, then heated at reflux for 1 hour. The reaction mixture was cooled to room temperature and evaporated under reduced pressure to give the crude product. The crude product was purified by flash column chromatography using an appropriate solvent system, as described for each individual procedure. 
Dimethyl-1,2-dihydropyridazine-1,2-dicarboxylate (2a) ${ }^{2}$

Using general procedure $C$, a mixture of hydrazine $\mathbf{S 1}(1.00 \mathrm{~g}, 6.74 \mathrm{mmol})$, iodobenzene diacetate (2.20 g, $6.75 \mathrm{mmol})$ and 1-acetoxy-1,3-butadiene $(1.2 \mathrm{~mL}, 10.1 \mathrm{mmol})$ in $\mathrm{CH}_{2} \mathrm{Cl}_{2}(2.7 \mathrm{~mL})$ was stirred at room temperature for 17 hours. After being passed through a short silica gel column (eluent: hexane-EtOAc, 2:1 $\rightarrow 1: 1)$, cycloadduct (1.72 g, $6.66 \mathrm{mmol}), \mathrm{Pd}(\mathrm{OAc})_{2}(15 \mathrm{mg}, 0.07 \mathrm{mmol})$, triphenylphosphine $(70 \mathrm{mg}, 0.27 \mathrm{mmol})$ and triethylamine $(1.9 \mathrm{~mL}, 13.3 \mathrm{mmol})$ in 1,4-dioxane (13 $\mathrm{mL}$ ) gave the crude product. Purification by flash column chromatography on silica gel (eluent: hexane-EtOAc, 4:1) gave dihydropyridazine 2 a (923 mg, $4.66 \mathrm{mmol}, 69 \%)$ as a yellow oil, which solidified to an off-white solid on standing. $R_{f}$ (Hexane-EtOAc, $2: 1$ ) $=0.26 ; \mathrm{mp}=62-64{ }^{\circ} \mathrm{C} ;{ }^{1} \mathrm{H} \mathrm{NMR}$ (400 MHz, $298 \mathrm{~K}, d_{6}$-DMSO); $\delta$ 6.92-6.66 (br m, 2H, NC=H), 5.92-5.70 (br m, 2H, NCHC=H), 3.74 $\left(\mathrm{s}, 6 \mathrm{H}, \mathrm{OCH}_{3}\right) ;{ }^{1} \mathrm{H}$ NMR (400 MHz, $348 \mathrm{~K}, d_{6}$-DMSO); $\delta 6.76$ (dd, $J=5.2,2.5 \mathrm{~Hz}, 2 \mathrm{H}, \mathrm{NC}=\mathrm{H}$ ), 5.81 $(\mathrm{dd}, J=5.2,2.5 \mathrm{~Hz}, 2 \mathrm{H}, \mathrm{NCHC}=H), 3.76\left(\mathrm{~s}, 6 \mathrm{H}, \mathrm{OCH}_{3}\right) ;{ }^{13} \mathrm{C} \mathrm{NMR}\left(100 \mathrm{MHz}, 298 \mathrm{~K}, d_{6}-\mathrm{DMSO}\right.$, additional peaks due to complex rate processes denoted by an asterisk); $\delta 153.8(\mathrm{C}=\mathrm{O}), 127.3$ $(\mathrm{NC}=\mathrm{H}), 113.4^{*}(\mathrm{NCHC}=\mathrm{H}), 112.1(\mathrm{NCHC}=\mathrm{H}), 53.7\left(\mathrm{OCH}_{3}\right) ;{ }^{13} \mathrm{C} \mathrm{NMR}\left(100 \mathrm{MHz}, 348 \mathrm{~K}, d_{6}-\mathrm{DMSO}\right) ; \delta$ $153.2(\mathrm{C}=\mathrm{O}), 127.0(\mathrm{NC}=\mathrm{H}), 112.2(\mathrm{NCHC}=\mathrm{H}), 53.2\left(\mathrm{OCH}_{3}\right)$; FTIR $(\mathrm{ATR}) \vee\left(\mathrm{cm}^{-1}\right): 2958,1715(\mathrm{C}=\mathrm{O})$; HRMS (APCI): $m / z$ calculated for: $\mathrm{C}_{8} \mathrm{H}_{10} \mathrm{~N}_{2} \mathrm{O}_{4}[\mathrm{M}+\mathrm{H}]^{+}$199.0713, found 199.0719.

\section{Diethyl 1,2-dihydropyridazine-1,2-dicarboxylate (2b)}

Using general procedure $B$, diethyl azodicarboxylate $(1.0 \mathrm{~mL}, 6.35 \mathrm{mmol})$ and 1-acetoxy-1,3butadiene $(1.1 \mathrm{~mL}, 9.53 \mathrm{mmol})$ in $\mathrm{CH}_{2} \mathrm{Cl}_{2}(1.3 \mathrm{~mL})$ was stirred at room temperature for 9 hours. After being passed through a short silica gel column (eluent: hexane-EtOAc, 5:1 $\rightarrow 2: 1$ ), cycloadduct ( $1.85 \mathrm{~g}, 6.44 \mathrm{mmol}), \mathrm{Pd}(\mathrm{OAc})_{2}(14 \mathrm{mg}, 0.06 \mathrm{mmol})$, triphenylphosphine $(67 \mathrm{mg}, 0.26$ $\mathrm{mmol}$ ) and triethylamine $(1.8 \mathrm{~mL}, 12.7 \mathrm{mmol})$ in 1,4-dioxane $(13 \mathrm{~mL})$ gave the crude product. Purification by flash column chromatography on silica gel (eluent: hexane-EtOAc, 9:1 $\rightarrow 4: 1$ ) gave dihydropyridazine $\mathbf{2 b}\left(1.29 \mathrm{~g}, 5.72 \mathrm{mmol}, 90 \%\right.$ ) as a white solid. $R_{f}$ (hexane-EtOAc, 1:1) =0.51; $\mathrm{mp}$ $=56-58{ }^{\circ} \mathrm{C} ;{ }^{1} \mathrm{H}$ NMR (400 MHz, $298 \mathrm{~K}, d_{6}$-DMSO); $\delta$ 6.89-6.65 (br m, 2H, NC=H), 5.89-5.72 (br m, $2 \mathrm{H}, \mathrm{NCHC}=H$ ), 4.24-4.09 (br m, 4H, OCH 2 ), 1.21 (br t, $\left.J=7.0 \mathrm{~Hz}, 6 \mathrm{H}, \mathrm{CH}_{2} \mathrm{CH}_{3}\right) ;{ }^{1} \mathrm{H}$ NMR $(400 \mathrm{MHz}$, $348 \mathrm{~K}, d_{6}$-DMSO); $\delta 6.75$ (br dd, $\left.J=5.2,2.5 \mathrm{~Hz}, 2 \mathrm{H}, \mathrm{NC}=\mathrm{H}\right), 5.79$ (br dd, J=5.2, $2.5 \mathrm{~Hz}, 2 \mathrm{H}, \mathrm{NCHC}=H$ ), 4.26-4.14 (m, $\left.4 \mathrm{H}, \mathrm{OCH}_{2}\right), 1.24\left(\mathrm{t}, J=7.1 \mathrm{~Hz}, 6 \mathrm{H}, \mathrm{CH}_{2} \mathrm{CH}_{3}\right) ;{ }^{13} \mathrm{C}$ NMR (100 MHz, $298 \mathrm{~K}, d_{6}-\mathrm{DMSO}$, additional peaks due to complex rate processes denoted by an asterisk); $\delta 153.2(\mathrm{C}=\mathrm{O}), 127.3$ $(\mathrm{NC}=\mathrm{H}), 113.2^{*}(\mathrm{NCHC}=\mathrm{H}), 111.9(\mathrm{NCHC}=\mathrm{H}), 62.6\left(\mathrm{OCH}_{2}\right), 14.2\left(\mathrm{CH}_{2} \mathrm{CH}_{3}\right) ;{ }^{13} \mathrm{C} \mathrm{NMR}(100 \mathrm{MHz}, 348$ $\mathrm{K}, d_{6}$-DMSO); $\delta 152.6(\mathrm{C}=\mathrm{O}), 127.0(\mathrm{NC}=\mathrm{H}), 112.0(\mathrm{NCHC}=\mathrm{H}), 62.2\left(\mathrm{OCH}_{2}\right), 13.8\left(\mathrm{CH}_{2} \mathrm{CH}_{3}\right) ; \mathrm{FTIR}$ $\left(\right.$ ATR) $\vee\left(\mathrm{cm}^{-1}\right): 3088,2989,1754$ (C=O), 1715 (C=O); HRMS (ESI): $\mathrm{m} / z$ calculated for: $\mathrm{C}_{10} \mathrm{H}_{14} \mathrm{~N}_{2} \mathrm{O}_{4}$ $[\mathrm{M}+\mathrm{Na}]^{+}$249.0846, found 249.0847 .

\section{Diisopropyl 1,2-dihydropyridazine-1,2-dicarboxylate (2c)}

Using general procedure $\mathrm{B}$, diisopropyl azodicarboxylate $(1.0 \mathrm{~mL}, 5.08 \mathrm{mmol})$ and 1-acetoxy-1,3butadiene $(0.9 \mathrm{~mL}, 7.62 \mathrm{mmol})$ in $\mathrm{CH}_{2} \mathrm{Cl}_{2}(1.0 \mathrm{~mL})$ was stirred at room temperature for 18 hours. After being passed through a short silica gel column (eluent: hexane-EtOAc, 7:1 $\rightarrow 3: 1$ ), cycloadduct ( $1.59 \mathrm{~g}, 5.05 \mathrm{mmol}), \mathrm{Pd}(\mathrm{OAc})_{2}(11 \mathrm{mg}, 0.05 \mathrm{mmol})$, triphenylphosphine $(54 \mathrm{mg}, 0.21$ $\mathrm{mmol})$ and triethylamine $(1.4 \mathrm{~mL}, 10.1 \mathrm{mmol})$ in 1,4-dioxane $(10 \mathrm{~mL})$ gave the crude product. Purification by flash column chromatography on silica gel (eluent: hexane-EtOAc, 14:1 $\rightarrow 7: 1$ ) gave dihydropyridazine $2 \mathrm{c}(1.06 \mathrm{~g}, 4.17 \mathrm{mmol}, 82 \%)$ as a white solid; $R_{f}$ (Hexane-EtOAc, 2:1) = 0.45; $\mathrm{mp}$ $=93-94{ }^{\circ} \mathrm{C} ;{ }^{1} \mathrm{H}$ NMR (400 MHz, $298 \mathrm{~K}, d_{6}$-DMSO); $\delta$ 6.86-6.64 (br m, 2H, NC=H), 5.90-5.67 (br m, 
$2 \mathrm{H}, \mathrm{NCHC}=H), 4.89(\mathrm{br}$ sept $, J=6.1 \mathrm{~Hz}, 2 \mathrm{H}, \mathrm{OCH}), 1.22\left(\mathrm{br} \mathrm{d}, J=6.1 \mathrm{~Hz}, 12 \mathrm{H}, \mathrm{CH}_{3}\right) ;{ }^{1} \mathrm{H}$ NMR $(400$ $\mathrm{MHz}, 348 \mathrm{~K}, d_{6}$-DMSO); $\delta 6.74$ (br dd, $\left.J=5.2,2.4 \mathrm{~Hz}, 2 \mathrm{H}, \mathrm{NC}=\mathrm{H}\right), 5.77$ (br dd, $J=5.2,2.4 \mathrm{~Hz}, 2 \mathrm{H}$, $\mathrm{NCHC}=H$ ), 4.91 (sept, $J=6.2 \mathrm{~Hz}, 2 \mathrm{H}, \mathrm{OCH}), 1.25\left(\mathrm{~d}, J=6.2 \mathrm{~Hz}, 12 \mathrm{H}, \mathrm{CH}_{3}\right) ;{ }^{13} \mathrm{C} \mathrm{NMR}(100 \mathrm{MHz}, 298$ $\mathrm{K}$, d6 -DMSO, additional peaks due to complex rate processes denoted by an asterisk); $\delta 152.6^{*}$ $(\mathrm{C}=\mathrm{O}), 151.9(\mathrm{C}=\mathrm{O}), 127.4(\mathrm{NC}=\mathrm{H}), 113.0^{*}(\mathrm{NCHC}=\mathrm{H}), 111.7(\mathrm{NCHC}=\mathrm{H}), 70.5(\mathrm{OCH}), 21.6\left(\mathrm{CH}_{3}\right) ;{ }^{13} \mathrm{C}$ $\operatorname{NMR}\left(100 \mathrm{MHz}, 348 \mathrm{~K}, d_{6}-\mathrm{DMSO}\right) ; \delta 152.1(\mathrm{C}=\mathrm{O}), 127.0(\mathrm{NC}=\mathrm{H}), 111.8(\mathrm{NCHC}=\mathrm{H}), 70.1(\mathrm{OCH}), 21.2$ $\left(\mathrm{CH}_{3}\right)$; FTIR (ATR) v $\left(\mathrm{cm}^{-1}\right): 3090,2986,1748(\mathrm{C}=0), 1711(\mathrm{C}=0)$; HRMS (APCI): $\mathrm{m} / \mathrm{z}$ calculated for: $\mathrm{C}_{12} \mathrm{H}_{18} \mathrm{~N}_{2} \mathrm{O}_{4}[\mathrm{M}+\mathrm{H}]^{+}$255.1339, found 255.1329.

\section{Di-tert-butyl 1,2-dihydropyridazine-1,2-dicarboxylate (2d)}

Using general procedure $\mathrm{B}$, di-tert-butyl azodicarboxylate $(1.00 \mathrm{~g}, 4.35 \mathrm{mmol})$ and 1-acetoxy-1,3butadiene $(0.8 \mathrm{~mL}, 6.53 \mathrm{mmol})$ in $\mathrm{CH}_{2} \mathrm{Cl}_{2}(1.7 \mathrm{~mL})$ was stirred at $40{ }^{\circ} \mathrm{C}$ for 2 days. After the addition of hexane $(20 \mathrm{~mL})$, filtration and drying, cycloadduct $(1.45 \mathrm{~g}, 4.23 \mathrm{mmol}), \mathrm{Pd}(\mathrm{OAc}){ }_{2}(10 \mathrm{mg}, 0.04$ $\mathrm{mmol}$ ), triphenylphosphine (44 mg, $0.17 \mathrm{mmol}$ ) and triethylamine $(1.2 \mathrm{~mL}, 8.5 \mathrm{mmol})$ in 1,4dioxane $(8.5 \mathrm{~mL})$ gave the crude product. Purification by flash column chromatography on silica gel (eluent: hexane-EtOAc, 19:1 $\rightarrow 9: 1$ ) gave dihydropyridazine $\mathbf{2 d}(912 \mathrm{mg}, 3.23 \mathrm{mmol}, 74 \%$ ) as a white solid. $R_{f}$ (Hexane-EtOAc, $\left.1: 1\right)=0.64 ; \mathrm{mp}=94-95{ }^{\circ} \mathrm{C} ;{ }^{1} \mathrm{H} \mathrm{NMR}\left(400 \mathrm{MHz}, 298 \mathrm{~K}, d_{6}\right.$-DMSO); $\delta$ 6.81-6.60 (br m, 2H, NC=H), 5.84-5.62 (br m, 2H, NCHC=H), $1.44\left(\mathrm{~s}, 18 \mathrm{H}, \mathrm{CH}_{3}\right) ;{ }^{1} \mathrm{H} \mathrm{NMR}(400 \mathrm{MHz}$, $\left.348 \mathrm{~K}, d_{6}-\mathrm{DMSO}\right) ; \delta 6.69$ (br dd, J = 5.3, $2.3 \mathrm{~Hz}, 2 \mathrm{H}, \mathrm{NC}=\mathrm{H}$ ), 5.71 (br dd, J=5.3, 2.3 Hz, 2H, NCHC=H), $1.46\left(\mathrm{~s}, 18 \mathrm{H}, \mathrm{CH}_{3}\right) ;{ }^{13} \mathrm{C}$ NMR $(100 \mathrm{MHz}, 298 \mathrm{~K}, \mathrm{~d} 6$-DMSO, additional peaks due to complex rate processes denoted by an asterisk); $\delta 151.8^{*}(\mathrm{C}=\mathrm{O}), 150.8(\mathrm{C}=\mathrm{O}), 127.6(\mathrm{NC}=\mathrm{H}), 111.9 *(\mathrm{NCHC}=H)$, $111.6(\mathrm{NCHC}=H), 111.1^{*}(\mathrm{NCHC}=H), 81.9\left(\mathrm{CO}_{2} \mathrm{C}\right), 27.6\left(\mathrm{CH}_{3}\right) ;{ }^{13} \mathrm{C} \mathrm{NMR}\left(100 \mathrm{MHz}, 348 \mathrm{~K}, d_{6}-\mathrm{DMSO}\right)$; $\delta 151.1(\mathrm{C}=\mathrm{O}), 127.2(\mathrm{NC}=\mathrm{H}), 111.3(\mathrm{NCHC}=\mathrm{H}), 81.5\left(\mathrm{CO}_{2} \mathrm{C}\right), 27.4\left(\mathrm{CH}_{3}\right) ; \mathrm{FTIR}(\mathrm{ATR}) \vee\left(\mathrm{cm}^{-1}\right): 2974$, $1733(\mathrm{C}=\mathrm{O}), 1718(\mathrm{C}=\mathrm{O})$; HRMS (ESI): $\mathrm{m} / \mathrm{z}$ calculated for: $\mathrm{C}_{14} \mathrm{H}_{22} \mathrm{~N}_{2} \mathrm{O}_{4}[\mathrm{M}+\mathrm{Na}]^{+} 305.1472$, found 305.1469 .

Scaled-up procedure: Using general procedure B, di-tert-butyl azodicarboxylate $(5.01 \mathrm{~g}, 21.7$ mmol) and 1-acetoxy-1,3-butadiene (3.9 mL, $32.6 \mathrm{mmol})$ in $\mathrm{CH}_{2} \mathrm{Cl}_{2}(4.4 \mathrm{~mL})$ was stirred at $40{ }^{\circ} \mathrm{C}$ for 2 days. After the addition of hexane $(40 \mathrm{~mL})$, filtration and drying, cycloadduct $(6.90 \mathrm{~g}, 20.2$ $\mathrm{mmol}), \mathrm{Pd}(\mathrm{OAc})_{2}(44 \mathrm{mg}, 0.20 \mathrm{mmol})$, triphenylphosphine $(216 \mathrm{mg}, 0.82 \mathrm{mmol})$ and triethylamine $(5.6 \mathrm{~mL}, 40.2 \mathrm{mmol})$ in 1,4-dioxane $(40 \mathrm{~mL})$ gave the crude product. Purification by flash column chromatography on silica gel (eluent: hexane-EtOAc, 19:1 $\rightarrow 14: 1 \rightarrow 9: 1$ ) gave dihydropyridazine 2d (4.40 mg, $15.6 \mathrm{mmol}, 72 \%$ ) as a white solid (spectroscopic data identical to those given above).

\section{Dibenzyl-1,2-dihydropyridazine-1,2-dicarboxylate (2e)}

Using general procedure $\mathrm{B}$, dibenzyl azodicarboxylate $(1.24 \mathrm{~g}, 4.00 \mathrm{mmol})$ and 1-acetoxy-1,3butadiene $(0.7 \mathrm{~mL}, 6.00 \mathrm{mmol})$ in $\mathrm{CH}_{2} \mathrm{Cl}_{2}(0.8 \mathrm{~mL})$ was stirred at room temperature for 2 hours. After being passed through a short silica gel column (eluent: hexane-EtOAc, 7:1 $\rightarrow 3: 1$ ), cycloadduct (1.53 g, $3.72 \mathrm{mmol}), \mathrm{Pd}(\mathrm{OAc})_{2}(9 \mathrm{mg}, 0.04 \mathrm{mmol})$, triphenylphosphine (42 mg, 0.16 mmol) and triethylamine $(1.1 \mathrm{~mL}, 7.89 \mathrm{mmol})$ in 1,4-dioxane $(8 \mathrm{~mL})$ gave the crude product. Purification by flash column chromatography on silica gel (eluent: hexane-EtOAc, 9:1 $\rightarrow 6: 1$ ) gave dihydropyridazine $2 \mathrm{e}(1.06 \mathrm{~g}, 3.02 \mathrm{mmol}, 75 \%)$ as a highly viscous orange oil; $R_{f}$ (Hexane-EtOAc, 2:1) = 0.37; ${ }^{1} \mathrm{H} \mathrm{NMR}\left(400 \mathrm{MHz}, 298 \mathrm{~K}, d_{6}\right.$-DMSO); $\delta$ 7.43-7.29 (br m, 10H, ArCH), 6.90-6.75 (br m, $2 \mathrm{H}, \mathrm{NC}=\mathrm{H}), 5.92-5.74(\mathrm{br} \mathrm{m}, 2 \mathrm{H}, \mathrm{NCHC}=\mathrm{H}), 5.31-5.16\left(\mathrm{br} \mathrm{m}, 4 \mathrm{H}, \mathrm{OCH}_{2}\right) ;{ }^{1} \mathrm{H} \mathrm{NMR}(400 \mathrm{MHz}, 348 \mathrm{~K}$, $d_{6}$-DMSO); $\delta$ 7.39-7.06 (br m, 10H, ArCH), 6.82 (dd, J = 5.2, 2.4 Hz, 2H, NC=H), 5.83 (dd, J = 5.2, 
$2.4 \mathrm{~Hz}, 2 \mathrm{H}, \mathrm{NCHC}=H), 5.26-5.19\left(\mathrm{br} \mathrm{m}, 4 \mathrm{H}, \mathrm{OCH}_{2}\right) ;{ }^{13} \mathrm{C} \mathrm{NMR}\left(100 \mathrm{MHz}, 298 \mathrm{~K}, d_{6}\right.$-DMSO, additional peaks due to complex rate processes denoted by an asterisk); $\delta 153.2(\mathrm{C}=0), 152.4^{*}(\mathrm{C}=\mathrm{O}), 135.6$ $(\mathrm{ArC}), 128.5(\mathrm{ArCH}), 128.2(\mathrm{ArCH}), 127.7(\mathrm{ArCH}$ or $\mathrm{NC}=\mathrm{H}), 127.2(\mathrm{ArCH}$ or $\mathrm{NC}=\mathrm{H}), 113.4^{*}(\mathrm{NCHC}=\mathrm{H})$, $112.2(\mathrm{NCHC}=\mathrm{H}), 67.8\left(\mathrm{OCH}_{2}\right) ;{ }^{13} \mathrm{C}$ NMR $\left(100 \mathrm{MHz}, 348 \mathrm{~K}, d_{6}-\mathrm{DMSO}\right) ; \delta 152.6(\mathrm{C}=0), 135.3(\operatorname{ArC})$, $128.0(\mathrm{ArCH}), 127.7(\mathrm{ArCH}), 127.2(\mathrm{ArCH}), 127.0(\mathrm{NC}=\mathrm{H}), 112.3(\mathrm{NCHC}=\mathrm{H}), 67.4\left(\mathrm{OCH}_{2}\right) ; \mathrm{FTIR}(\mathrm{ATR})$ $v\left(\mathrm{~cm}^{-1}\right)$ : 3032, 2954, 1716 (C=O); HRMS (ESI): $\mathrm{m} / z$ calculated for: $\mathrm{C}_{20} \mathrm{H}_{18} \mathrm{~N}_{2} \mathrm{O}_{4}[\mathrm{M}+\mathrm{Na}]^{+} 373.1159$, found 373.1148 .

1-tert-Butyl-2-methyl-1,2-dihydropyridazine-1,2-dicarboxylate (2f)

Using general procedure $C$, a mixture of hydrazine $\mathbf{S 2}(1.02 \mathrm{~g}, 5.27 \mathrm{mmol})$, iodobenzene diacetate (1.78 g, $5.54 \mathrm{mmol}$ ) and 1-acetoxy-1,3-butadiene $(0.9 \mathrm{~mL}, 7.89 \mathrm{mmol})$ in $\mathrm{CH}_{2} \mathrm{Cl}_{2}(5.3 \mathrm{~mL})$ was stirred at $40{ }^{\circ} \mathrm{C}$ for 24 hours. After being passed through a short silica gel column (eluent: hexaneEtOAc, 7:1 $\rightarrow 2: 1)$, cycloadduct $(1.47 \mathrm{~g}, 4.90 \mathrm{mmol}), \mathrm{Pd}(\mathrm{OAc})_{2}(24 \mathrm{mg}, 0.11 \mathrm{mmol})$, triphenylphosphine $(110 \mathrm{mg}, 0.42 \mathrm{mmol})$ and triethylamine $(1.5 \mathrm{~mL}, 10.5 \mathrm{mmol})$ in 1,4-dioxane $(10.5 \mathrm{~mL})$ gave the crude product. Purification by flash column chromatography on silica gel (eluent: hexane-EtOAc, 7:1 $\rightarrow 5: 1)$ gave dihydropyridazine $2 \mathrm{f}(577 \mathrm{mg}, 2.40 \mathrm{mmol}, 46 \%)$ as an offwhite solid. $R_{f}$ (Hexane-EtOAc, $2: 1$ ) $=0.37 ; \mathrm{mp}=70-72{ }^{\circ} \mathrm{C} ;{ }^{1} \mathrm{H} \mathrm{NMR}\left(400 \mathrm{MHz}, 298 \mathrm{~K}, d_{6}\right.$-DMSO); $\delta$ 6.84-6.60 (br m, 2H, 2 x NC=H), 5.87-5.64 (br m, 2H, 2 x NCHC=H), 3.73 (br s, 3H, OCH $), 1.43$ (br $\left.\mathrm{s}, 9 \mathrm{H}, \mathrm{C}-\mathrm{CH}_{3}\right) ;{ }^{1} \mathrm{H} \mathrm{NMR}\left(400 \mathrm{MHz}, 348 \mathrm{~K}, d_{6}\right.$-DMSO); $\delta$ 6.74-6.70 (br m, 2H, $\left.2 \times \mathrm{NC}=\mathrm{H}\right), 5.78-5.72$ (br m, 2H, $2 \times \mathrm{NCHC}=H), 3.75\left(\mathrm{~s}, 3 \mathrm{H}, \mathrm{OCH}_{3}\right), 1.45\left(\mathrm{~s}, 9 \mathrm{H}, \mathrm{C}-\mathrm{CH}_{3}\right) ;{ }^{13} \mathrm{C} \mathrm{NMR}\left(100 \mathrm{MHz}, 298 \mathrm{~K}, d_{6}-\right.$ DMSO, additional peaks due to complex rate processes denoted by an asterisk); $\delta 153.7(\mathrm{C}=\mathrm{O})$, 152.8* $(\mathrm{C}=\mathrm{O}), 151.8(\mathrm{C}=\mathrm{O}), 127.8(\mathrm{NC}=\mathrm{H}), 127.0(\mathrm{NC}=\mathrm{H}), 113.0^{*}(\mathrm{NCHC}=\mathrm{H}), 112.1(\mathrm{NCHC}=\mathrm{H})$, $111.1(\mathrm{NCHC}=\mathrm{H}), 82.3\left(\mathrm{CO}_{2} \mathrm{C}\right), 53.5\left(\mathrm{OCH}_{3}\right), 27.6\left(\mathrm{C}-\mathrm{CH}_{3}\right) ;{ }^{13} \mathrm{C} \mathrm{NMR}\left(100 \mathrm{MHz}, 348 \mathrm{~K}, d_{6}-\mathrm{DMSO}\right) ; \delta$ $153.0(\mathrm{C}=\mathrm{O}), 151.2(\mathrm{C}=\mathrm{O}), 127.4(\mathrm{NC}=\mathrm{H}), 126.8(\mathrm{NC}=\mathrm{H}), 112.0(\mathrm{NCHC}=\mathrm{H}), 111.4(\mathrm{NCHC}=\mathrm{H}), 81.9$ $\left(\mathrm{CO}_{2} \mathrm{C}\right), 52.9\left(\mathrm{OCH}_{3}\right), 27.4\left(\mathrm{C}-\mathrm{CH}_{3}\right)$; FTIR (ATR) v $\left(\mathrm{cm}^{-1}\right)$ : 2984, $1748(\mathrm{C}=0), 1716$ (C=O); HRMS (APCI): $\mathrm{m} / \mathrm{z}$ calculated for: $\mathrm{C}_{11} \mathrm{H}_{16} \mathrm{~N}_{2} \mathrm{O}_{4}[\mathrm{M}-\mathrm{H}]^{-} 239.1037$, found 239.1029 .

\section{1-Benzyl-2-tert-butyl-1,2-dihydropyridazine-1,2-dicarboxylate (2g)}

Using general procedure $C$, a mixture of hydrazine $\mathbf{S 3}(1.01 \mathrm{~g}, 3.77 \mathrm{mmol})$, iodobenzene diacetate (1.27 g, $3.94 \mathrm{mmol}$ ) and 1-acetoxy-1,3-butadiene $(0.67 \mathrm{~mL}, 5.63 \mathrm{mmol})$ in $\mathrm{CH}_{2} \mathrm{Cl}_{2}(1.5 \mathrm{~mL})$ was stirred at room temperature for 17 hours. After being passed through a short silica gel column (eluent: hexane-EtOAc, 7:1 $\rightarrow 3: 1)$, cycloadduct (1.23 g, $3.27 \mathrm{mmol}), \mathrm{Pd}(\mathrm{OAc})_{2}(15 \mathrm{mg}, 0.07 \mathrm{mmol})$, triphenylphosphine $(68 \mathrm{mg}, 0.26 \mathrm{mmol}$ ) and triethylamine $(0.9 \mathrm{~mL}, 6.54 \mathrm{mmol})$ in 1,4-dioxane $(6.5 \mathrm{~mL})$ gave the crude product. Purification by flash column chromatography on silica gel (eluent: hexane-EtOAc, 14:1 $\rightarrow 7: 1$ ) gave dihydropyridazine $\mathbf{2 g}(658 \mathrm{mg}, 2.08 \mathrm{mmol}, 55 \%$ ) as highly viscous orange oil. $R_{f}$ (Hexane-EtOAc, $\left.2: 1\right)=0.45 ;{ }^{1} \mathrm{H}$ NMR (400 MHz, $298 \mathrm{~K}, d_{6}$-DMSO); $\delta 7.43-$ 7.27 (br m, 5H, ArCH), 6.86-6.68 (br m, 2H, 2 x NC=H), 5.89-5.67 (br m, 2H, 2 x NCHC=H), 5.375.04 (br m, 2H, OCH 2 ), 1.50-1.19 (br s, 9H, C-CH 3 ); ${ }^{1} \mathrm{H}$ NMR (400 MHz, $\left.348 \mathrm{~K}, d_{6}-\mathrm{DMSO}\right) ; \delta 7.40-$ 7.31 (br m, 5H, ArCH), 6.78-6.72 (m, 2H, 2 x NC=H), 5.81-5.73 (m, 2H, 2 x NCHC=H), 5.26-5.18 (m, $\left.2 \mathrm{H}, \mathrm{OCH}_{2}\right), 1.41\left(\mathrm{~s}, 9 \mathrm{H}, \mathrm{C}-\mathrm{CH}_{3}\right) ;{ }^{13} \mathrm{C} \mathrm{NMR}\left(100 \mathrm{MHz}, 298 \mathrm{~K}, d_{6}\right.$-DMSO, additional peaks due to complex rate processes denoted by an asterisk); $\delta 153.2$ (C=O), 152.3 (C=O), 135.7 (C10), 128.4 $(\mathrm{ArCH}), 128.2(\mathrm{ArCH}), 127.8(\mathrm{ArCH}), 127.4(\mathrm{NC}=\mathrm{H}), 126.9(\mathrm{NC}=\mathrm{H}), 113.1^{*}(\mathrm{NCHC}=\mathrm{H}), 112.3$ $(\mathrm{NCHC}=\mathrm{H}), 111.2^{*}(\mathrm{NCHC}=\mathrm{H}), 82.4\left(\mathrm{CO}_{2} \mathrm{C}\right), 67.5\left(\mathrm{OCH}_{2}\right), 27.6\left(\mathrm{C}_{-} \mathrm{CH}_{3}\right) ;{ }^{13} \mathrm{C} \mathrm{NMR}(100 \mathrm{MHz}, 348 \mathrm{~K}$, $d_{6}$-DMSO); $\delta 152.5(\mathrm{C}=\mathrm{O}), 151.3(\mathrm{C}=\mathrm{O}), 135.4(\mathrm{ArC}), 128.0(\mathrm{ArCH}), 127.7(\mathrm{ArCH}), 127.5(\mathrm{NC}=\mathrm{H})$, 
127.3 (ArCH), $126.7(\mathrm{NC}=\mathrm{H}), 112.2(\mathrm{NCHC}=\mathrm{H}), 111.5(\mathrm{NCHC}=\mathrm{H}), 82.0\left(\mathrm{CO}_{2} \mathrm{C}\right), 67.2\left(\mathrm{OCH}_{2}\right), 27.3(\mathrm{C}-$ $\left.\mathrm{CH}_{3}\right)$; FTIR (ATR) v $\left(\mathrm{cm}^{-1}\right): 2978,1713(\mathrm{C}=\mathrm{O})$; HRMS (ESI): $\mathrm{m} / z$ calculated for: $\mathrm{C}_{17} \mathrm{H}_{20} \mathrm{~N}_{2} \mathrm{O}_{4}[\mathrm{M}+\mathrm{Na}]^{+}$ 339.1315 , found 339.1316 .

\section{2-Phenyl-[1,2,4]triazolo[1,2-a]pyridazine-1,3-dione $(\mathbf{2 h})^{5}$}

Using general procedure $C$, a mixture of 4-phenyl urazole $(1.03 \mathrm{~g}, 5.82 \mathrm{mmol})$, iodobenzene diacetate $\left(1.88 \mathrm{~g}, 5.85 \mathrm{mmol}\right.$ ) and 1-acetoxy-1,3-butadiene $(1.0 \mathrm{~mL}, 8.46 \mathrm{mmol})$ in $\mathrm{CH}_{2} \mathrm{Cl}_{2}(10 \mathrm{~mL})$ was stirred at room temperature for 1 hour. After the addition of hexane $(20 \mathrm{~mL})$, filtration and drying, cycloadduct $(1.64 \mathrm{~g}, 5.69 \mathrm{mmol}), \mathrm{Pd}(\mathrm{OAc})_{2}(13 \mathrm{mg}, 0.07 \mathrm{mmol})$, triphenylphosphine $(60$ $\mathrm{mg}, 0.23 \mathrm{mmol})$ and triethylamine $(1.6 \mathrm{~mL}, 11.4 \mathrm{mmol})$ in 1,4-dioxane $(11 \mathrm{~mL})$ gave the crude product. Purification by flash column chromatography on silica gel (eluent: hexane-EtOAc, 1:1) gave dihydropyridazine $\mathbf{2 h}(957 \mathrm{mg}, 4.21 \mathrm{mmol}, 72 \%)$ as a yellow solid. The spectroscopic data are consistent with those reported previously. ${ }^{4}{ }^{1} \mathrm{H} \mathrm{NMR}\left(400 \mathrm{MHz}, \mathrm{CDCl}_{3}\right) ; \delta 7.54-7.38(\mathrm{br} \mathrm{m}, 5 \mathrm{H}$, $\mathrm{ArCH}), 6.88(\mathrm{br} \mathrm{dd}, J=6.1,2.7 \mathrm{~Hz}, 2 \mathrm{H}, \mathrm{NC}=\mathrm{H}), 5.34(\mathrm{br} \mathrm{dd}, J=6.1,2.7 \mathrm{~Hz}, 2 \mathrm{H}, \mathrm{NCHC}=H) ;{ }^{13} \mathrm{C} \mathrm{NMR}$ $\left(100 \mathrm{MHz}, \mathrm{CDCl}_{3}\right) ; \delta 142.7$ (C=O), 131.0 (ArC), 129.4 ( $\left.\mathrm{ArCH}\right), 128.7$ (ArCH), 125.8 (ArCH), 120.9 $(\mathrm{NC}=\mathrm{H}), 105.2(\mathrm{NCHC}=\mathrm{H})$.

\section{ASSOCIATED CONTENT}

\section{Supporting Information}

The Supporting Information is available free of charge on the ACS Publications website.

Detailed experimental procedures and spectroscopic data for precursors, ${ }^{1} \mathrm{H}$ and ${ }^{13} \mathrm{C}$ NMR spectra (including variable-temperature spectra) and X-ray crystallographic data of new compounds (PDF).

\section{Accession Codes}

CCDC 1825113 contains the supplementary crystallographic data for this paper. These data can be obtained free of charge via www.ccdc.cam.ac.uk/data_request/cif, or by emailing data_request@ccdc.cam.ac.uk, or by contacting The Cambridge Crystallographic Data Centre, 12 Union Road, Cambridge, CB2 1EZ, UK; fax: +44 1223336033.

\section{AUTHOR INFORMATION}

\section{Corresponding Author}

*E-mail: s.coote@lancaster.ac.uk

\section{ORCID}

Thomas K. Britten: 0000-0002-3580-1145 
Geoff R. Akien: 0000-0002-2247-064X

Paul D. Kemmitt: 0000-0002-5374-6557

Nathan R. Halcovitch: 0000-0001-6831-9681

Susannah C. Coote: 0000-0002-3590-9113

\section{Notes}

The authors declare no competing financial interest.

\section{ACKNOWLEDGMENTS}

This research was supported by Lancaster University and an AstraZeneca CASE Top-Up Award.

\section{REFERENCES}

(1) (a) Altman, L. J.; Semmelhack, M. F.; Hornby, R. B; Vederas, J. C. J. Chem. Soc., Chem. Commun. 1968, 686. (b) Altman, L. J.; Semmelhack, M. F.; Hornby, R. B.; Vederas, J. C. Org. Prep. Proced. Int. 1975, 7, 35.

(2) Warrener, R. N.; Nunn, E. E.; Paddon-Row, M. N. Aust. J. Chem. 1979, 32, 2659.

(3) Stearns, R. A.; Ortiz de Montellano, P. R. J. Am. Chem. Soc., 1985, 107, 234.

(4) Whitman, D. W.; Carpenter, B. K. J. Am. Chem. Soc. 1980, 102, 4272.

(5) Sheradsky, T.; Moshenberg, R. J. Org. Chem. 1985, 50, 5604.

(6) Rink, M.; Mehta, S.; Grabowski, K. Arch. Pharm. 1959, 292, 225.

(7) Rigaudy, J.; Brelière, J. C. Bull. Soc. Chim. Fr. 1968, 455.

(8) Ried, W.; Reiher, U. Chem. Ber. 1987, 120, 1597.

(9) Ball, C. J.; Gilmore, J.; Willis, M. C. Angew. Chem. Int. Ed. 2012, 51, 5718.

(10) (a) Sheradsky, T.; Moshenberg, R. J. Org. Chem. 1984, 49, 587 (b) Sheradsky, T.; Moshenberg, R. J. Org. Chem. 1986, 51, 3123.

(11) For pioneering work on palladium-mediated elimination of allylic acetates: (a) Smutny, E. J. Am. Chem. Soc. 1967, 89, 6793. (b) Tsuji, J.; Yamakawa, T.; Kaito, M.; Mandai, T. Tetrahedron Lett. 1978, 19, 2075. (c) Trost, B. M.; Verhoeven, T. R.; Fortunak, J. M. Tetrahedron Lett. 1979, 20, 2301.

(12) Anderson, J. E.; Lehn, J.-M. Tetrahedron, 1968, 24, 137.

(13) (a) Butcher, S. S.; J. Chem. Phys., 1965, 42, 1830. (b) Traetteberg, M. Acta Chem. Scand. 1968, 22, 2305. (c) Oberhammer, H.; Bauer, S. H. J. Am. Chem. Soc. 1969, 91, 10. (d) Auf der Heyde, W.; Lüttke, W. Chem. Ber. 1978, 111, 2384.

(14) Fisher, T. H.; Crook, J. C.; Chang, S. Tetrahedron, 1987, 43, 2443.

(15) Kaftory, M.; Fisher, T. H.; Dershem, S. M. J. Chem. Soc. Perkin Trans. II, 1989, 1887.

(16) (a) Brelière, J. C.; Lehn, J.-M. Chem. Commun. 1965, 426. (b) Daniels, R.; Roseman, K. A. Tetrahedron Lett. 1966, 7, 1335. (c) Bushweller, C. H. Chem. Commun. 1966, 80. (d) Price, B.; Sutherland, I. O.; Williamson, F. G. Tetrahedron, 1966, 22, 3477. (e) Daniels, R.; Roseman, K. A. J. Am. Chem. Soc. 1966, 88, 429. (f) Anderson, J. E.; Lehn, J.-M. J. Am. Chem. Soc. 1967, 
89, 81. (g) Anderson, J. E.; Lehn, J.-M. Tetrahedron 1968, 24, 123. (h) Bittner, E. W.; Gerig, J. T. J. Am. Chem. Soc. 1972, 94, 913. (i) Bynum, K.; Rothchild, R. Spectrosc. Lett. 1997, 30, 1713. 